THE BLACK KINGDOM OF THE NILE

The Nathan I. Huggins Lectures 



\section{The Black Kingdom of the Nile}

\section{CHARLES BONNET}

With a Foreword by Henry Louis Gates, Jr.

HARVARD UNIVERSITY PRESS

Cambridge, Massachusetts

London, England

2019 
Copyright (@) 2019 by the President and Fellows of Harvard College All rights reserved

Printed in the United States of America

First printing

Jacket art: Jacket photograph: B.N. Chagney OKAPArcheo.com

Jacket Design: Annamarie McMahon Why

9780674239043 (EPUB)

9780674239050 (MOBI)

9780674239036 (PDF)

The Library of Congress has cataloged the printed edition as follows:

Names: Bonnet, Charles, 1933- author. | Gates, Henry Louis, Jr., writer of foreword.

Title: The Black kingdom of the Nile / Charles Bonnet, with a foreword by

Henry Louis Gates, Jr.

Description: Cambridge, Massachusetts : Harvard University Press, 2019. |

Includes bibliographical references and index.

Identifiers: LCCN 2018040574 | ISBN 9780674986671 (hardcover : alk. paper)

Subjects: LCSH: Kerma (Extinct city) | Excavations (Archaeology)—Nubia. | Archaeology and history—Nile River Valley. | Nubia—Antiquities. | Nubia—History. | Nile River Valley-Antiquities.

Classification: LCC DT159.6.N83 B65 2019| DDC 939/.7801—dc23

LC record available at https://lccn.loc.gov/2018040574 